\title{
The Ability of National Selection Students to Enter State Universities (SNMPTN) in Following the Lecture Process at the Faculty of Education, Universitas Negeri Medan
}

\author{
$1^{\text {st }}$ Yusnadi $^{1}, 2^{\text {nd }}$ Zuraidah Lubis ${ }^{2}, 3^{\text {rd }}$ Kamtini $^{3}$ \\ \{yusnadi@unimed.id.ac ${ }^{1}$ \} \\ Universitas Negeri Medan \\ Out Of School Education Study Program, Faculty of Education ${ }^{1}$, Guidance and \\ Counseling Study Program, Faculty of Education ${ }^{2}$, Guidance and Counseling Study \\ Program, Faculty of Education ${ }^{3}$, Teacher education for early childhood Faculty of \\ Education $^{4}$, \\ Jalan Willem Iskandar, Sumatera Utara, Indonesia
}

\begin{abstract}
This study aims to analyze the ability of students especially work attitudes during lesson learning. The indicators used to measure work attitudes which are include accuracy, work speed, work endurance and achievement motivation. The method used is descriptive with a mixed method approach. The population of this study was all students who entered higher education through SNMPTN at Faculty of Education. The sample was determined using the Slovin formula and obtained 96 students. Data collection is collected through psychological tests. The data were analyzed using descriptive statistics. The results showed that only a small proportion of students' work attitudes were in the high category $(9,4 \%)$. While most are in the medium category $(66.7 \%)$ and some are in the low category (24.0). From each indicator, most of the students are in the medium category, but on the work endurance indicator, most of the students are in the low category.
\end{abstract}

Keywords: Ability, work attitude, accuracy, work speed, work endurance, achievement motivation.

\section{Introduction}

The National Selection for State Universities Admission or commonly abbreviated as SNMPTN is one of the policies in student admissions to enter state universities which is carried out simultaneously throughout Indonesia. Initially, SNMPTN consisted of two pathways, namely invited SNMPTN (such as PMDK) that based on report books during senior high school and the others one is SNMPTN that based on written exams. In 2013, the written SNMPTN was changed its name to the Joint Selection for State University Entrance (SBMPTN) and the SNMPTN with the invitation to prospective student later changed its name to SNMPTN with admission selection criteria based on school report paper, National Examination scores, and other academic achievements. 
Within the framework of integrating secondary education with higher education, schools are given a role in the SNMPTN selection process. Schools as educational units and teachers as educators are assumed to always uphold honor and honesty. Therefore, schools are obliged to fill out the School and Student Database (PDSS) which contains a complete and correct track record of school performance and student academic achievement. Thus, the principles of being credible, fair, transparent, flexible, efficient, and accountable and non-discriminatory should be the basic benchmark in determining student graduation for new students.

Universities as education providers accept prospective students who have high academic achievements at the high school level and are predicted to be successful in completing their studies on time. This prediction is based on the assumption that students who excel at high school will consistently show their achievements when they attend lectures.

Based on various sources, several problems were found regarding the selection of students with the SNMPTN pathway. First, although SNMPTN uses an assessment with report cards that can better describe students' abilities while sitting in high school, there are several cases where it is suspected that report cards tend to be manipulated so that prospective students who enter higher education do not have the ability and qualified quality [1]. Second, related to the recruitment system that is not transparent and open, so that many prospective students do not know the clear assessment criteria related to the implementation of SNMPTN. Third, several studies have revealed differences in academic achievement that students enter the SNMPTN and SBMPTN pathways. Research conducted on Gajah Mada University students, showed that the average GPA of SBMPTN students was higher than that of SNMPTN, with an average GPA of 3.33 for SBMPTN and 3.11 for SNMPTN [2]. Likewise with other studies, found that there are differences in student achievement in terms of admission, namely; Invitation track, SNMPTN, and Independent Selection Path (Mandiri). Furthermore, based on analysis of student achievement during learning process the result showed that the Invitation selection score of mean acquisition is 2.8895 , the mean score of SNMPTN is 2.9800 , and the mean score of Mandiri is 2.8268 with a significance level of $0.001 \%$ [3]

From these studies, it is indicated that there are differences in students' abilities in attending lectures based on their entry path. Students who are accepted through the national written exam have better achievements than the invited or independent route.

The term ability has many meanings, ability has the meaning of ability, skill, strength in carrying out an action or activity [4]. Ability is a rational behavior to achieve the required goals in accordance with the expected conditions [5]. Ability can be associated with learning, so that learning ability is a form of growth or change in a person which is expressed in new ways of behaving thanks to experience and practice. As example ability seen from student perform to find new information, the emergence of new understandings, changes in attitudes, habits, skills, the ability to appreciate the development of social, emotional, and physical characteristics [6]. Ability can be understood as a result of changes in a child's behavior after learning. Ability also can described by the value of numbers or letters of a person.[7]

The ability to attend lectures in the sense of learning, in this research is interpreted as a skill in mastering one skill and being used to do various tasks in a learning activities. This skill affects the potential that exists within the individual and has an influence on the ability of students to attend lectures. Each student's ability is different. This ability ultimately becomes the basic potential that exists in students as individuals, and ultimately affects the ability of each student as an individual in attending lectures.

The lecturing process which is then interpreted as learning requires students to optimize all the skills they have, but based on interviews conducted with several lecturers at the Faculty of Education, admitted that some students who were accepted through the SNMPTN selection 
had difficulties in attending lectures or learning. In addition, there is a difference in performance between students who are accepted through the SNMPTN pathway, and the SBMPTN where students with the SBMPTN pathway are more able to adapt to various assignments and lecture materials given.

This of course will have an impact on the quality of graduates produced by Faculty of Eduaction of State Universitas Negeri Medan (Unimed). The quality of good graduates will certainly affect the standard of a quality education system. For example, Finland, which is now the country with the best education system, is due to teachers who have good competence and quality. This condition, of course, begins with a highly selective recruitment system. Based on the data, getting into the University of Helsinki teacher education program is more difficult (6.8 percent acceptance rate) than law programs (8.3\% acceptance rate) or medical programs (7.3 percent acceptance rate) in 2016 [8] .

Based on the explanation of the background that has been explained, we assumed that not all students who enter through the SNMPTN selection have good abilities in attending lectures, facing various obstacles and or obstacles in attending lectures. Furthermore, based on the assumption, the SNMPTN selection implement standard rules might not conduct properly and transparently in the process of determining prospective students through the SNMPTN selection.

Based on the background that has been described, it is necessary to conduct an in-depth scientific study of the ability of students to attend lectures seen from the policy of the student recruitment system through the SNMPTN selection pathways.

\section{Method}

Research focuses on policy implementation, which is a research that examine to test a policy that is being implemented or has already been implemented [9]. If it is being implemented, it aims to improve the quality, effectiveness, and efficiency of the policy, while if the policy research is carried out when the policy has been implemented or implemented, it aims to assess the policy as a whole. The approach used is the mix method, which is a combination of two qualitative and quantitative approaches. Mix method has several advantage such as more comprehensive, valid, reliable, and objective data, that will be obtained regarding the ability of students who are accepted through the SNMPTN route in attending lectures.

There are several stage on this research, which are :

a. Formulating the problem as the focus of policy research

b. Collect field data

c. Analyze data

d. Formulate research results

e. Formulate recommendations for policy makers and implementers.

f. Conduct mentoring and evaluation

The research was conducted at the Faculty of Education (FIP) Universitas Negeri Medan, which includes all study programs, namely: (1) Guidance and Counseling Study, (2) Elementary School Teacher Education Study, (3) Early Childhood Education Teacher Study, and (4) Society Community Education. All students who entered the 2018-2020 SNMPTN pathway were used as the research population of 523 people. Sampling was carried out using the Slovin formula, and obtained a sample size of 96 students. 
Data collection instruments in the form of questionnaires and psychological tests. The questionnaire instrument has been tested for validity and reliability at the $95 \%$ confidence level using the corrected item-total correlation method Product moment formula and reliability is tested using the Cronbach Alpha method. The psychological tests used are intelligence tests, aptitude tests, interest tests, using the Binet Simon test. Data were analyzed with descriptive statistics, comparative analysis to determine which indicators best support student readiness in attending lectures.

\section{Result and Discussion}

Based on the results of the psychological test indicators, students' abilities were measured using indicators of general intelligence, work attitude, and personality, each indicator consisting of sub-indicators as presented in Table 1.

Table 1. Variable, sub variable and indicator.

\begin{tabular}{llll}
\hline No & Variable & Sub Variable & \multicolumn{1}{c}{ Indicator } \\
\hline \multirow{3}{*}{1} & Students Ability & Accuracy \\
\cline { 3 - 3 } & & Work Attitudes & Working Speed \\
\cline { 3 - 3 } & & Work Durability \\
\cline { 3 - 3 } & & Achievement motivation \\
\hline
\end{tabular}

The measurement of student ability variables as measured by accuracy indicators is presented in Figure 1. Based on Figure 1, it is concluded that the percentage of student accuracy for the high category is $9.4 \%$, then for the medium category is $66.7 \%$ and $24 \%$ for low category.

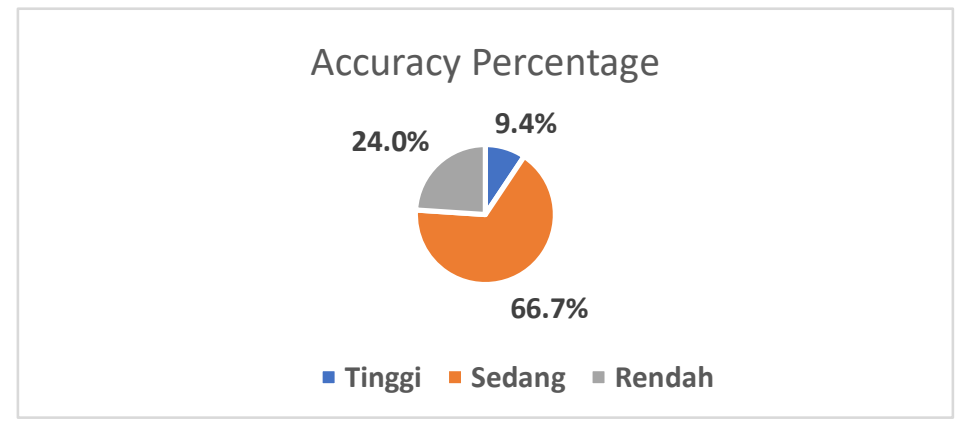

Fig. 1. Overall accuracy percentage. 
Furthermore, Figure 2 shows the results of the analysis for the accuracy indicators in each study program.

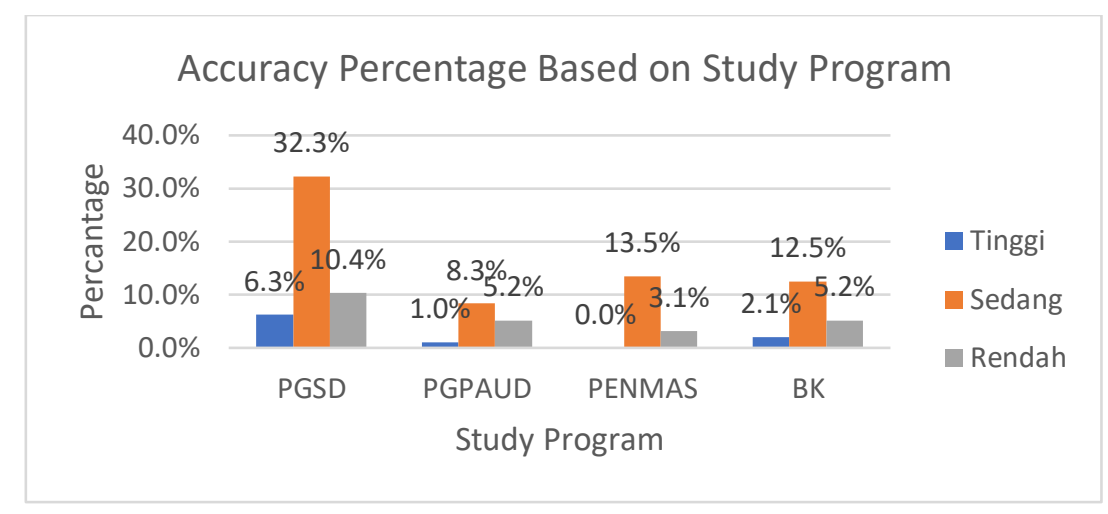

Fig. 2. Percentage of accuracy in each study program.

The measurement of student ability variables as measured by working speed indicators is presented in Figure 3. Based on Figure 3, it is concluded that the percentage of student working speed for the high category is only $1 \%$, then for the medium category is $53.1 \%$ and $45.8 \%$ is low.

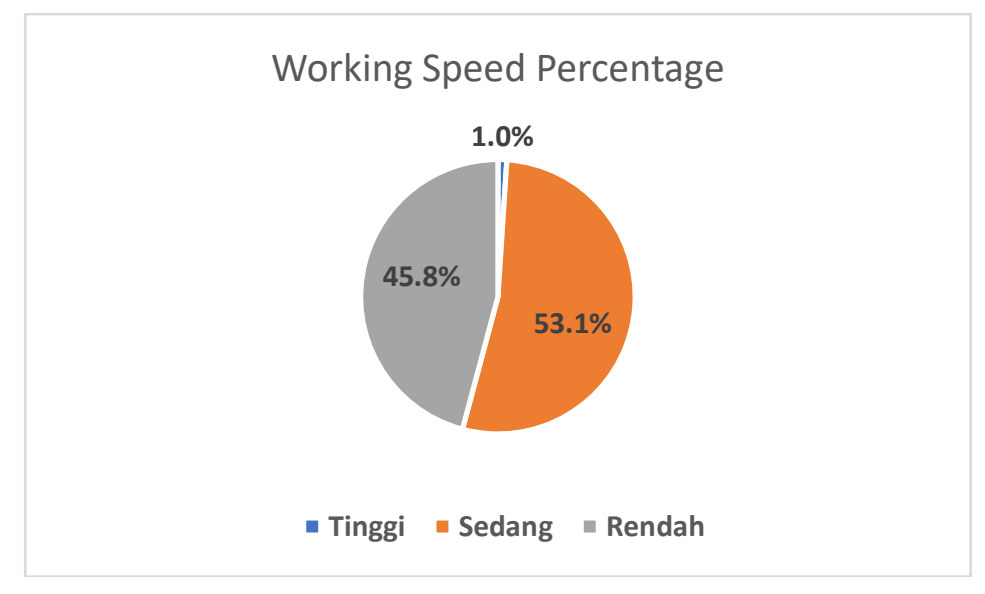

Fig. 3. Overall working percentage

Furthermore, Figure 4 shows the results of the analysis for the working speed indicators in each study program. 


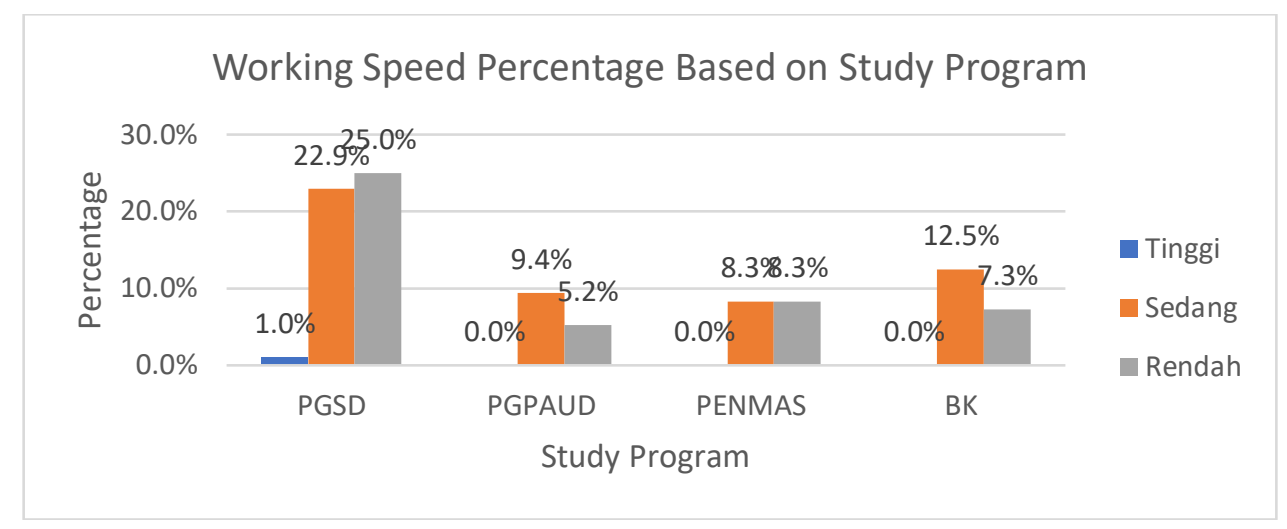

Fig. 4. Percentage of working speed in each study program.

The measurement of student ability variables as measured by working durability indicators is presented in Figure 5. Based on Figure 5, it is concluded that the percentage of student working durability for the high category is only $1 \%$, then for the medium category is $26 \%$ and $72.9 \%$ for low category.

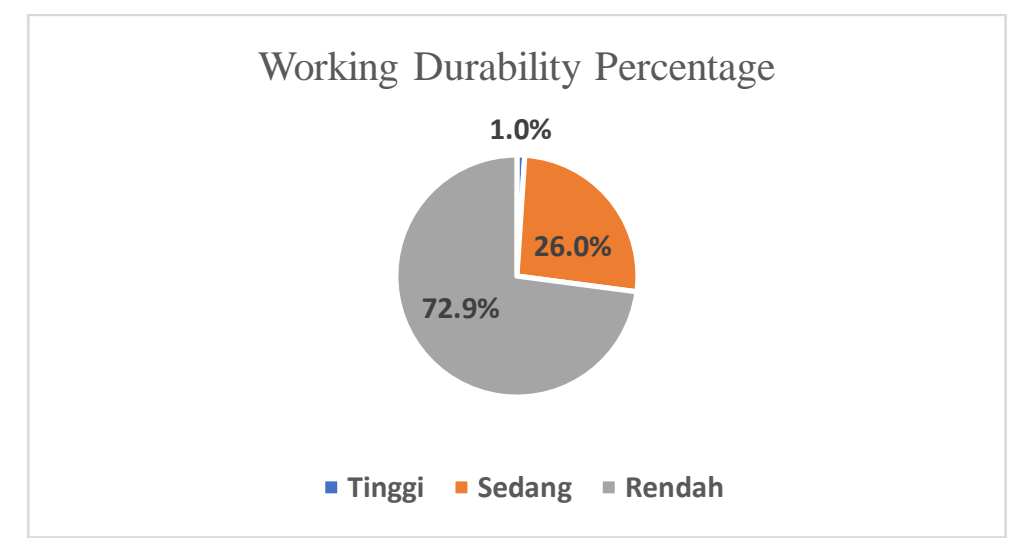

Fig. 5. Overall working durability percentage.

Furthermore, Figure 6 shows the results of the analysis for the working durability indicators in each study program. 


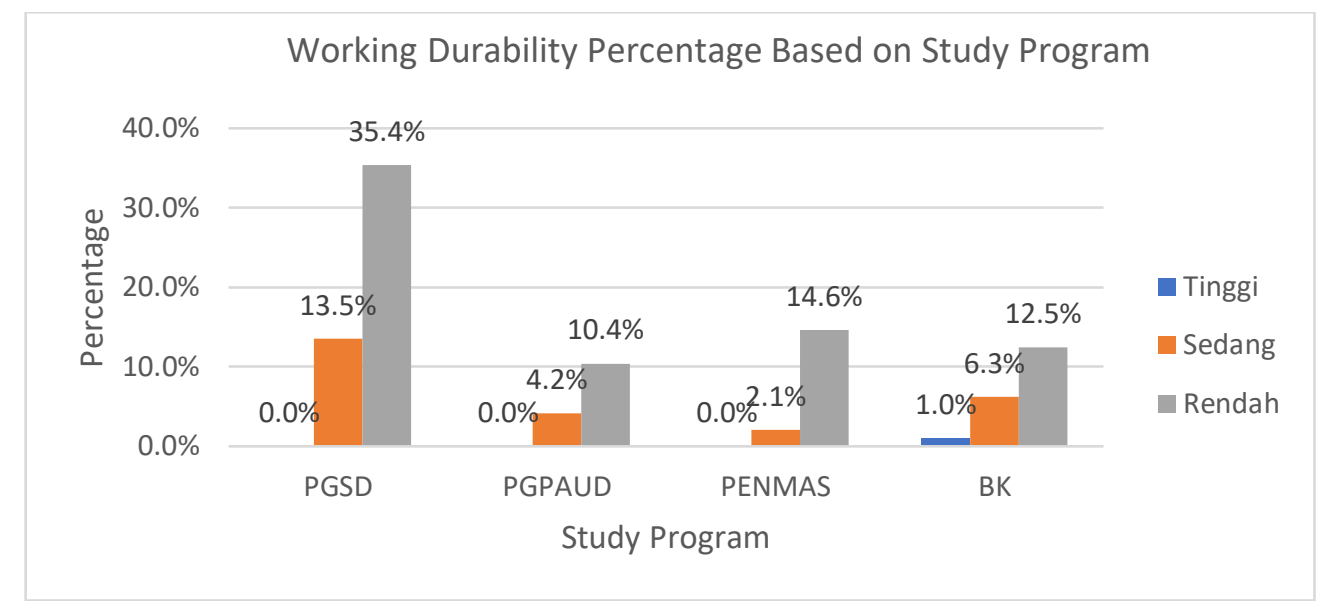

Fig. 6. Percentage of working durability in each study program.

The measurement of student ability variables as measured by achievement motivation indicators is presented in Figure 7. Based on Figure 7, it is concluded that the percentage of student achievement motivation for the high category is only $8,3 \%$, then for the medium category is $57,3 \%$ and $34,4 \%$ for low category.

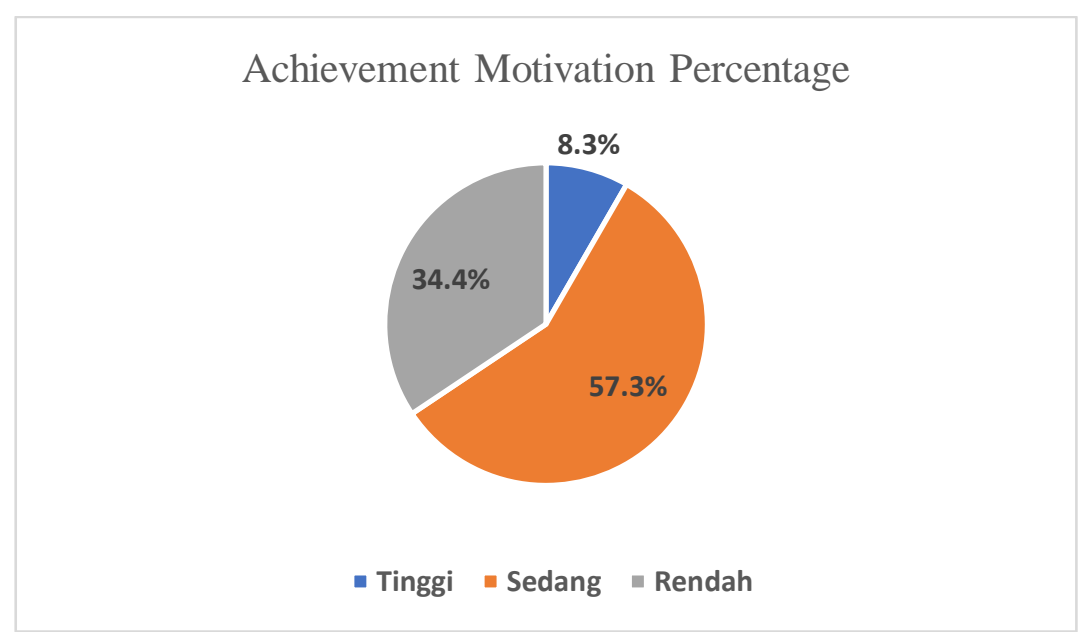

Fig. 7. Overall achievement motivation percentage.

Furthermore, Figure 8 shows the results of the analysis for the achievement motivation indicators in each study program. 


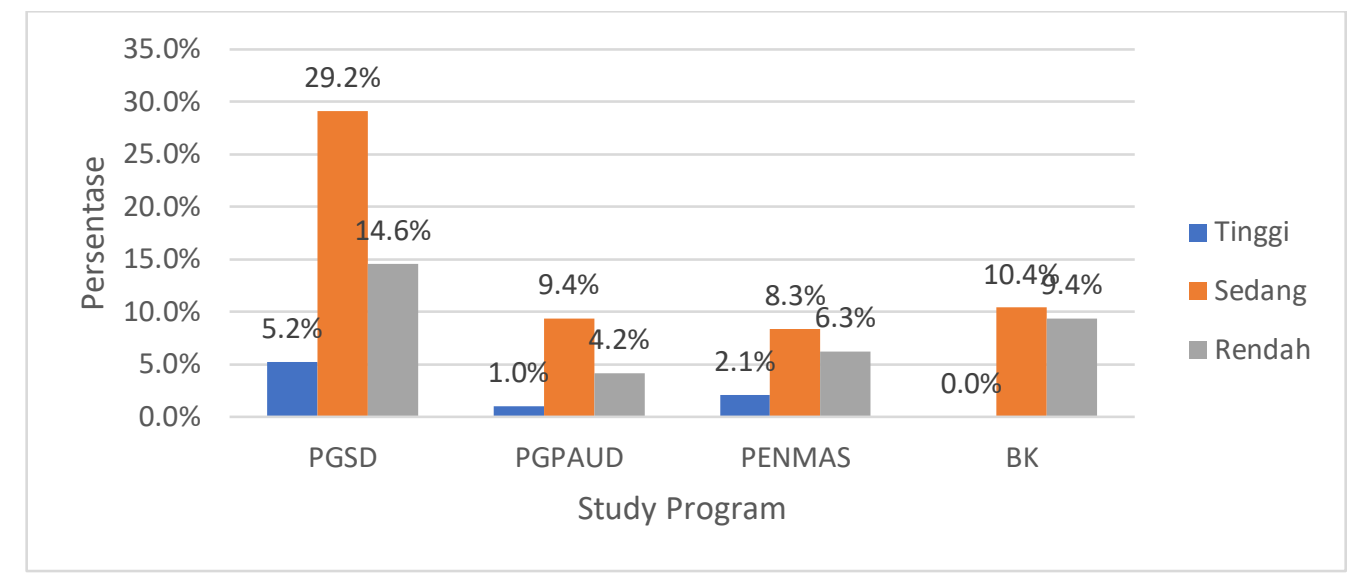

Fig. 8. Percentage of achievement motivation in each study program.

Work attitude is one of the student ability variables that should be taken seriously into the admissions of SNMPTN selection. This variable is important because it includes accuracy, work speed, work endurance, achievement motivation. These indicators are student internal factors that are closely related to student achievement. It is recognized that there are many other influential factors, such as: intelligence which includes conceptual ability, analytical power, capture power, and personality aspects (self-confidence, self-adjustment, cooperation, and emotional stability).

In the accuracy indicator, overall only a small proportion of students are in the high category $(9.4 \%)$, while most of the others are in the medium category $(66.7 \%)$ and others are in the low category (24.0). Then on the work speed indicator, from all respondents it shows that only a small percentage $(1.0 \%)$ are in the high category. Then, the other in medium category $(53.1 \%), 45.8 \%$ are in the low position. Based on the result, the ability to work speed is still in the category that does not support the maximum performance of students.

Further analysis of work durability, it shows that most $(72.9 \%)$ of the students are in the low category, thus is medium category are $26.0 \%$, and only a small proportion $(1 \%)$ are in the high category. In fact, this endurance is a factor needed by every student to be able to attend lectures to the fullest. With regard to achievement motivation, like other indicators, only a small portion $(8.3 \%)$ are in the high category, while $(57.3 \%)$ is in the medium position and $34.4 \%$ are in the low category.

Many experts argue that achievement motivation is related to achievement. Based on the findings, low achievement motivation may have an effect on the poor achievement of SNMPTN students at the Faculty of Education.

\section{Conclusion}

Research carried out with a mixed method approach has resulted in students' abilities in attending lectures which are traced through work attitude variables. The indicators used in measuring work attitudes include accuracy, work speed, work endurance, achievement 
motivation. In general, students' work attitudes are in the medium category level. Further analysis from each indicator of work attitude, which are accuracy, speed of work, and achievement motivation shows the indicators are in the medium category, while for working durabilty, most of particapants are in low category.

\section{References}

[1] Ibtisam F. Kuota SNMPTN terus dikurangi jalur undangan dinilai kurang efektif. Available from:https://rencanamu.id/post/sudut-pandang/kuota-snmptn-terus-dikurangi-jalur-undangandinilai-kurang-efektif [Accessed $13^{\text {th }}$ March 2015].

[2] Nigrum TP, Prestasi Akademik Mahasiswa Ditinjau dari Sistem Jalur Penerimaan Mahasiswa Baru di Universitas Gadjah Mada. Yogyakarta: Universitas Gadjah Mada; 2014.

[3] Saputra K, Eka A. Studi Komparatif Prestasi Belajar Mahasiswa Jurusan Pendidikan Ekonomi Ditinjau Dari Jalur Penerimaan Mahasiswa Baru Tahun 2011. Jurnal Jurusan Pendidikan Ekonomi. 2016;6(1).

[4] Poerwadarminta WJ. Kamus Umum Bahasa Indonesia. Jakarta: Balai Pustaka; 2002.

[5] Cece W, Rusyan A, Tambrani. Pendekatan Dalam Proses Belajar Mengajar. Bandung: Remaja Karya; 2002.

[6] Hamalik, Oemar. Kemampuan Belajar. Jakarta: Bumi Aksara; 2004.

[7] Semiawan, Conny. Belajar dan Pembelajaran dalam Taraf Usia Anak Dini. Jakarta: Prehallindo; 2002.

[8] Detiknews. Lebih Mudah Jadi Dokter Ketimbang Guru di Finlandia, Ini Alasannya. Available from:https://news.detik.com/berita/d-4797209/lebih-mudah-jadi-dokter-ketimbang-guru-difinlandia-ini-alasannya/2. [Accessed $12^{\text {th }}$ March 2021].

[9] Sugiyono. Metode Penelitian Kebijakan Pendekatan Kuantitatif, Kualitatif, Kombinasi, R \& D dan Penelitian Evaluasi. Bandung: Alfabeta; 2001. 